VOSZKA ÉVA ${ }^{1}$

JÓLÉTI ÁLLAM

Keynes és a köztulajdon

DOI: 10.18030/SOCIO.HU.2018.1.95

\title{
ABSZTRAKT
}

A fejlett európai országokban az állami tulajdon 1945 után több hullámban is kiterjedt, miközben kialakultak a „keynesi jóléti állam” különböző változatai. A tanulmány ennek a két folyamatnak a kapcsolatát vizsgálja, pontosabban azt, hogy adtak-e elméleti hátteret az államosításokhoz a keynesi, illetve jóléti teóriák. A nem teljes körű és csak a tulajdonlás kérdésére összpontosító elemzés következtetése az, hogy az államosítások szilárd elméleti alapok nélkül indultak. Csak az állami szerep növekedésének általános, a keynesi jóléti államban összegződő keretfeltételei adtak nekik hátszelet - de természetesen ez sem kevés.

Kulcsszavak: állami tulajdon, államosítás, jóléti állam elméletek, keynesianizmus

\section{WELFARE STATE}

Keynes and state ownership

\section{ABSTRACT}

In the developed countries of Europe, state ownership expanded in several waves after World War II, when various types of "Keynesian welfare states" emerged. This paper raises the question of whether the theory of Keynes and the theories of the welfare state give sound fundamentals for taking private firms into state hands. The non-exhaustive analysis of related conservative, social democratic and academic approaches concludes that nationalization started without any theoretical background. The process was boosted only by the general expansion of state interventions, justified by Keynesian principles.

Keywords: state ownership, nationalization, theories of welfare state, Keynesianism 


\section{JÓLÉTI ÁLLAM}

Keynes és a köztulajdon

\section{Kedves Juli,}

Keresve sem találhatnék jobb bizonyitékot a nyitottságodra és olthatatlan kiváncsiságodra - ami egyébként szerintem az örökifiúság titka -, mint a születésnapi csokorba szánt rövid irás sorsát. Elolvastál egy félkész, kicsit zürös, a te témáiddal alig érintkező kéziratot, ráadásul Amerikában, ahol nyilván száz más dolgod-bajod volt. És szokás szerint éles szemmel vetted észre a logikai buktatókat, a gyönge pontokat, a meg nem gondolt gondolatokat. Közéjük tartozott a „jóléti állam” kapcsolódása a készülő könyv tárgyához, az államositási és privatizációs hullámokhoz.

A megjegyzéseid, mint mindig, inspirálóak voltak. Próbáltam javitani a szövegen, de tudom, hogy ez még most sem az igazi. Ennek ellenére kérlek, ne utasitsd vissza ezt a szerény kis virágot.

A jóléti állam kifejezés általában a fejlett országokban a második világháború után kiépült, a piacot a kormányzati beavatkozás változatos formáival kombináló rendszerek általános megjelölésére szolgál, amit „jóléti kapitalizmusnak” vagy „keynesi jóléti államnak” is szokás nevezni. Annak a készülő könyvnek a tárgya, amelyből ez a részlet származik, az állami tulajdon. Ezért a fő kérdés az, hogy adott-e a fejlett országok 1945 utáni államosítási hullámaihoz elméleti hátteret az időszak két fontos irányzata, a jóléti és a keynesi teória. Kérdéses az is, hogy mennyire megalapozott ennek a két eszmekörnek az összekapcsolása, hol érintkeznek, van-e választóvonal közöttük. Viszonyukat már csak azért sem könnyű elemezni, mert egyiknek sincs általánosan elfogadott meghatározása. A jóléti állam és Keynes elmélete is összetett, képlékeny, utat nyit az egymástól eltérő felfogásoknak. Ezért ez az írás először külön-külön veszi őket szemügyre, majd megkísérli értelmezni a kapcsolatukat, és összegi az állami tulajdonhoz füződő viszonyuk tanulságait.

Az elemzés korlátozott lesz, mert egyrészt nem vállalkozik arra, hogy a jóléttel, a jóléti állammal foglalkozó teóriák teljes körét feldolgozza, csak néhány jellegzetesnek tekinthető elméletet emel ki közülük. Másrészt ezeknek is csak a kontúrjait vázolja fel, és mindvégig a tulajdonra, illetve e szempont felvetésének hiányára fókuszál - az utóbbira próbál legalább részleges magyarázatot adni.²

2 Köszönettel tartozom a cikk két anonim lektorának, akik kritikus megjegyzéseikkel az írás első változatának jelentős átdolgozásra késztettek. 


\section{A „JÓLÉTI KAPITALIZMUS"}

A jóléti elméleteknek két generációja különböztethető meg, amelyeknek nemcsak a keletkezési ideje, hanem - részben ebből adódóan - a megközelítése is eltér egymástól. A korai, második világháború előtti teóriák a többféleképpen felfogott jólétről és az állam ebben betöltött szerepéről szólnak, zömmel normatív módon, gyakorlati javaslatokat is megfogalmazva. Ezek azután sokszor befolyásolták is a politikai döntéseket. A második hullám a már múködő rendszerek létrejöttének okait, társadalmi feltételeit, következményeit vizsgálja, típusokat is alkotva - voltaképpen ezek a jóléti állam pozitív teóriái.

A korai jóléti felfogások a 19. századtól kezdve a dolgozó osztályok időnként gazdasági válságokkal és háborúkkal is súlyosbított nyomorára, az ennek talaján szerveződő radikális mozgalmakra, a robbanással fenyegető társadalmi feszültségekre reagáltak, ezek enyhítését túzték ki célul, a forradalmi változások elkerülése érdekében. Közös a kiindulópont, a szabad piaci berendezkedés (korabeli szóhasználattal: a manchesterizmus) bírálata, és közös a részben morális megfontolásokra építő javaslatok alapiránya is: a szegénység enyhítése, a szociális biztonság erősítése, mégpedig reformok útján, állami közremúködéssel. A kapitalizmus kereteit a konzervatív irányzatok nem, a szocialista-szociáldemokrata megközelítések pedig csak békés, fokozatos módon akarták átlépni. Ezeket az elgondolásokat mutatom be a teljesség igénye nélkül néhány példával, amelyek egyik csoportja társadalmi mozgalmakhoz, a másik az akadémiai tudományhoz kapcsolódik, és egyben illusztrálják az állami tulajdonhoz füződő viszony több változatát is.

A konzervatív vonal egyik reprezentánsa a német katedraszocializmus, ${ }^{3}$ amely hatást gyakorolt a korabeli szociális törvényhozásra is. Az úttörőnek tekintett bismarcki rendszer az 1880-as évektől bevezette az egészségügyi, baleset-és nyugdíjbiztosítás elemeit - szelektíven, zömmel az ipari munkásokra, alkalmazásban lévőkre korlátozva - és jórészt a munkaadók, munkavállalók hozzájárulására, nem pedig állami forrásokra építve.

A katedraszocializmus elnevezésének alapja az, hogy képviselőik, mint Gustav Schmoller, Lujo Brentano és Adolf Wagner professzorokként a „szociális kérdés” megoldását tartották a fő feladatnak - hasonlóan a nem sokkal korábban még törvényen kívülre szorított, akkor még radikális német szociáldemokrata párthoz. A javasolt eljárás azonban lényegesen különbözött a szociáldemokratákétól: az egyetemi tudósok nemcsak a liberális laissez faire elveket vetették el, hanem a szocializmust, a forradalmi átalakulást is. Éppen ennek elhárítása érdekében szorgalmazták az igazságosabb elosztást, a szegény- és középrétegek erkölcsi-anyagi felemelését - amit pedig az államnak kell megvalósítania. Nagyobb kormányzati szerepet javasoltak tehát, de nem a termelésbentulajdonlásban, hanem a források és javak elosztásában. Noha általános érvényű gazdasági törvények létét megkérdőjelezték, ezt uralkodó tendenciaként is megfogalmazták. A társadalom fejlődésével együtt - állítja a nevezetes Wagner-törvény - az összjövedelmen belül nő az állami kiadások részaránya az iparosítás, a népességnövekedés és az urbanizáció következtében, a szükséges infrastrukturális beruházások, a jólét, a magasabb rendű szükségletek megjelenése miatt. Wagner szerint a nemzetgazdaságnak (Volkswirtschaft) államgazdasággá (Staatswirtschaft) kell válnia, amelynek alapja a „jólét”. Az a felfogás, amely szerint a munkaerő áru, és a 
munkabér ennek ára, nem humánus és nem keresztény ${ }^{4}$ - vitatkozik explicit módon a marxizmussal, egyben megelőlegezve a későbbi, Esping-Andersenhez köthető felfogás egyik kulcspontját.

Míg a katedraszocialisták konzervatív alapállásukból következően nem vették számításba az állami tulajdonlás lehetőségét, a szocialisztikus indíttatású, de a forradalmi átalakulást szintén elvető angol fábiánusok hosszú távon ezt tartották kívánatosnak: „a termelési eszközök ellenőrzése a közösség által, a köz érdekében... a nyereség és a kamat kollektiv elsajátítása a közösség által” (Webb 1890: 4). Úgy látták azonban, hogy az általuk egyedül elfogadható demokratikus megközelítéssel ez a cél csak fokozatosan érhető el, de változatos eszközökkel: a magántulajdon korlátozásával, államosításokkal és szociálpolitikával.

Álláspontjuk szerint a munkástömegek nyomora nem szüntethető meg, amíg fennáll a „termelési eszközök korlátozatlan magántulajdona" (Webb 1890: 12, kiemelés az eredetiben). Csakhogy a legfejlettebb országban már sok korlátozás megvalósult az adózással és számos ipari ágazat szabályozásával. Terjed a szövetkezeti és még inkább a helyhatósági tulajdon - a víz- és gázszolgáltatásban, a városi közlekedésben -, amelynek bővítését Webb a mozgalom lapjában folyamatosan szorgalmazta (például 1891a, b, c). Örömmel látta az állami foglalkoztatás és tulajdonlás növekedését is (bíróságok, iskolák, posta, a közlekedés és a közszolgáltatások egy része) - majd az első világháború után a szakszervezetek delegáltjaként a továbblépés egyik élharcosa lett. Már korábban is úgy gondolta, hogy a folyamat megállíthatatlan, és elvezet a nagy részvénytársaságok, végül a föld közösségi ellenőrzéséhez. Nem utópiákat és a jövő társadalom részletes tervezetét kell felrajzolni - írja -, hanem a tendenciák felismerésével és az azokat akadályozó, önző érdekek elhárításával kell lépésről lépésre előre haladni. A szegénység és az elnyomás fennmaradása ismét társadalmi kataklizmához vezetne, amit csak a szociáldemokrácia fokozatos elterjedése tud elhárítani.

A fábiánusok alapvető szerepet tulajdonítottak a szociálpolitikának is. „A társaság tagjai megállapítják fogalmazták meg célkitúzésüket 1883-ban, az alapításkor-, hogy a kompetitiv rendszer kevesek boldogságát és kényelmét sokak szenvedése árán biztosítja, és hogy a társadalmat úgy kell átalakitani, hogy az általános jólétet és boldogságot teremtsen" (Pease 1916: 32).

A sok szempontból úttörő megközelítés szerint a szegénység nem morális-egyéni, hanem strukturális probléma, amelynek elsősorban a megelőzésére, nem pedig megbélyegző, büntető jellegú kezelésére kell törekedni. A nyomorúságos helyzetet újratermelő, megalázó dologházak és a tüneti enyhítést jelentő egyéni jótékonykodás helyett az állam feladata, hogy adókból és a felhasználók hozzájárulásából mindenki számára, univerzálisan biztosítsa a „civilizált élethez” szükséges oktatási, egészségügyi szolgáltatásokat, a gyermekek, az idősek és a rokkantak ellátását, továbbá hogy elősegítse a foglalkoztatás, a bérek növelését. Jelszavuk a „nemzeti minimum" volt, ami egyrészt bérminimum meghatározását jelentette azoknak, akik dolgoztak, másrészt kielégítő támogatást a munkaképteleneknek.

Ezeket a szegénység-törvényeken alapuló korabeli brit rendszer kritikájaként megfogalmazott elveket egy évekig tartó parlamenti bizottsági munka több száz oldalas jelentése, a nevezetes Minority Report fejti ki

4 Idézi Briggs (1961: 29). Meg kell jegyezni, hogy a katolikus egyház, majd a keresztényszocialista mozgalmak szintén behatóan foglalkoztak a szegénységgel, a jóléttel és a munkáskérdéssel (lásd például XIII. Leo és XI. Pius enciklikáit 1891-ből és 1931-ből), de ezekre itt nem térünk ki. 
(Webb-Webb 1909). ${ }^{5}$ A fábiánusok javaslatait a liberális kormány nem fogadta el, de az első világháború előtt reformtörvényeket hozott a gyermekvédelemről, a nyugdíj- és egészségbiztosításról, amelyek szigorú feltételek mellett jórészt a szegényeket érintették, továbbá néhány ágazatban bevezették a minimálbért is. Ám az akkor kisebbségben maradt elvek később közvetlenül - a kidolgozásukban fiatal tanácsadóként résztvevő, majd 1942ben átfogó programot előterjesztő William Henry Beveridge révén - beépültek a brit rendszer átalakításába.

A radikális, diktatúrával fenyegető változásokat a 19. és 20. század fordulóján a szociáldemokrácia egyes irányzatai, a marxi-lenini elveket felülvizsgáló „revizionista” megközelítések is elutasították. A reformista szociáldemokraták közül a német Eduard Heimann például úgy vélte, hogy a szociálpolitika idegen elemet visz a kapitalizmus rendszerébe, így ez lesz az a trójai faló, amely segít átlépni a kapitalizmus és a szocializmus határát (idézi Espig-Andersen 1990: 11). Ha a határt ennek alapján húzzuk meg, akkor érthető, hogy nincs szükség a radikális előfutárok által alapvető elemnek tekintett tulajdonlás kiemelt kezelésére. Részletesebben a svéd esetet idézzük fel, mert ez a tulajdonlásról is újszerú megközelítést tartalmazó elmélet, és gyakorlati alkalmazására már a második világháború előtt sor kerülhetett.

A Hjalmar Branting vezette szociáldemokrata párt kezdettől „integratív demokráciát” hirdetett: a piacot nem megszüntetni, hanem csak korlátozni kell, így felhasználva azt alapértékeik - egyenlőség, szabadság, szolidaritás, együttműködés, biztonság - megvalósításához. ${ }^{6}$ Bár programjukban az 1910-es évek végén szerepelt a tulajdon nagy léptékű „szocializálása”, de ezt elvetették a számukra riasztó orosz tapasztalatokra, a hadigazdálkodással szembeni társadalmi ellenszenvre, az alacsonyabb hatékonyságra, valamint a tókések várható ellenállására hivatkozva. Úgy ítélték meg, hogy „... a perdöntő elem nem a formális tulajdonjog, hanem az ellenörzéshez szükséges hatalom" (Tilton 1979: 515).

A teoretikus háttér a Nils Karleby nevéhez köthető „hagymaelmélet,” vagy más megfogalmazásban a „funkcionális tulajdon”.7 Eszerint a tulajdon nem pusztán fizikai tőke, nem oszthatatlan egység, amelyet egyszerre kell kisajátítani, hanem - kimondatlanul is a tőke, mint termelési viszony marxi elvét követve - jogok „kötege.” Így egyes részei leválaszthatók, és lépésről lépésre társadalmi befolyás alá rendelhetők. „Ez a felfogás az alapja annak, hogy a kapitalisták elöjogait fokozatosan bontsuk el, mint a hagymahéjakat, amíg semmi nem marad belőlük" (Karlebyt idézi Berman 2006: 168). A lebontás módszere pedig egyfelől a progresszív adózás, az erős szabályozás, másfelől a jóléti intézkedések sora, amihez később a gazdasági tervezés és az ipari (vállalaton belüli) demokrácia erősítése társult.

Ernst Wigforss, a svéd szociáldemokrácia egyik legbefolyásosabb teoretikusa a fokozatosság jegyében, Karleby elméletét elfogadva, az államosítást is mérték kérdésének tekintette: ez esetenként indokolt lehet, de önmagában nem alkalmas a szociáldemokrata célok elérésére (Tilton 1979). A kistulajdont elvileg sem szükséges közkézbe venni - állította -, mert abban a tőke és a munka összekapcsolódik, a nagyvállalatok kisajátítása 5 Elemzését lásd például Wallis (2009).

6 Mivel az eredeti írásokat nem találtam meg fordításban, ez az ismertetés másodlagos forrásokra épít, elsősorban Tilton (1979), Loppert (2003), Berman (2006) elemzéseire.

7 Ezzel szó szerint megegyezik a fábiánusokhoz, majd a keresztényszocialistákhoz közel álló angol Tawney megfogalmazása: „A tulajdon nem egyetlen jog, hanem jogok kötege" (1922: 123), aki nyerészkedő társadalom helyett funkcionális társadalmat gondolt el. Ebben a békés és fokozatos köztulajdonba vételnek tulajdonított meghatározó szerepet. Az elsőséget, illetve azt, hogy a két szerző ismerte-e egymás munkáját, a rendelkezésre álló forrásokból nem sikerült megállapítanom. 
pedig állami túlhatalomhoz vezetne. A „szocializálás” elvileg sem jó megoldás, mert a kapitalizmus hibáit nem önmagában a magántulajdon okozza, hanem a piaci mechanizmusok szélsőséges hatásai. Az ipar államosítása a piac megszervezése nélkül nem hatékony, igazságtalan és antidemokratikus kapitalizmushoz vezetne, ellentmondva a szocialista értékeknek. Ezeknek az érveknek az alapján Wigforss gyakorló politikusként a radikális tulajdonosi döntések helyett sokfajta szabályozást valósított meg a tőke korlátozására, és már az 1920-as években közmunkaprogramokat indított a munkanélküliség csökkentésére és a kereslet növelésére, hangsúlyozva a multiplikátor hatásokat is. A nagy válság idején a svédek minden más országnál, sőt az elmélet részletes kifejtésénél is előbb alkalmazták a később „keynesianizmusnak” nevezett gyakorlatot (Berman 2006). Ugyanakkor élen jártak a szociális juttatások területén is, amelyek - részben az emancipatorikus elvek, részben a szavazóbázis kiterjesztésének praktikus szempontja miatt, széles körű koalícióra támaszkodva - az univerzális, osztályhatárokat átlépő szolidaritásra épültek, a lakosság nagy részét bevonták a rendszerbe. ${ }^{8}$

A pártpolitikától távol álló, akadémikus közgazdászok közül Arthur Cecil Pigout emelhetjük ki, aki talán elsőként helyezte átfogó munkájának középpontjába a jólétet. Az Economics of Welfare kiindulópontja az, hogy a közgazdaságtudomány vezérlő elve nem a kíváncsiság, hanem a társadalmi együttérzés az elesettekkel, „a hervadó életek örömtelenségével" (Pigou 1920 I.1: 1). A könyv tematikája a szociálpolitikánál sokkal szélesebb körű, lényegében a jövedelem termelésének és elosztásának minden területére kiterjed. Alapvető megközelítése nem normatív, hanem mérlegelő: sorra veszi a lehetséges megoldásokat, bemutatja előnyeiket és hátrányaikat az általános jólét, illetve az egyes társadalmi osztályok szempontjából. Álláspontja általában a piac kombinálása az óvatos állami beavatkozással. Ez jellemzi a szociálpolitikával kapcsolatos állami újraelosztás alapvető formáinak (nyugdíj, egészségügy, oktatás, a gyermeknevelés támogatása) és a foglalkoztatásnak, a béreknek - köztük a minimálbérnek - a tárgyalását. Hasonlóképpen közelíti meg az állami tulajdon ügyét is, amelynek külön fejezetet szentel.

A köztulajdonba vétel kérdése azért merülhet fel - írja -, mert a tapasztalatok szerint a szabályozás, különösen a monopóliumok megregulázása nehézségekbe ütközik. Pigou az állami és magántulajdont a technikai (múködési) hatékonyság alapján próbálja összehasonlítani, de rögtön megállapítja, hogy ez nem egyszerü: a statisztikai adatok a szolgáltatások minőségének eltérései miatt szinte teljesen használhatatlanok, továbbá „....a magáncég müködése számos különböző dolgot jelenthet, ... csakúgy, mint az állam müködése” (II. XXII: 13). Ezért általánosságban semmit sem mondhatunk arról, hogy melyik hatékonyabb; ezt mindig konkrétan, az összes körülmény figyelembe vételével kell mérlegelni. A feltételek sorában Pigou kiemelten vizsgálja, hogy a vállalkozás szabályozott piacon múködik-e vagy sem, mekkora az adott területen a kockázatvállalás, az új találmányok (ma azt mondanánk, innovációk) jelentősége, milyen szervezeti keretek között gyakorolja tulajdonosi szerepét az állam vagy a helyhatóság, milyen ösztönzőket szab meg a vállalatvezetők számára. E felfogásnak megfelelően a következtetések is valószínúségeket fogalmaznak meg: a köztulajdon hatékonyabb lehet a monopóliumok, a regulált iparágak, a lassan változó piacok esetében, és akkor, ha az állam független

8 Lásd részletesen Esping-Andersen (1990). E politika kidolgozásában részt vett a párt fiatal gazdaságpolitikai tanácsadója, Gunnar Myrdal is, aki később a svéd szociáldemokraták nemzetközileg legismertebb képviselője lett. Írásainak egyik fontos része a jóléti állammal foglalkozik; a szociális, különösen az oktatási kiadásokat nem költségnek, hanem produktív befektetésnek, az emberi tőke minőségi fejlesztésének tekintette. Nézeteiről jó összefoglalót ad a Morel és szerzőtársai által szerkesztett kötet (2012) bevezető tanulmánya. 
hatóságok útján, viszonylag kevés beavatkozással (nem termelési mennyiségek vagy módszerek előírásával) gyakorolja tulajdonosi jogait.

Szerepel az állami tulajdon a fábiánus körből induló William Beveridge elgondolásaiban is. Noha ebben az esetben nem elméletről, hanem nagyon is praktikus, a kormány számára kidolgozott javaslatról van szó, fő vonásait érdemes bemutatni az átfogó jelleg és a nemzetközi hatás miatt: ezen alapult a második világháború utáni angol szociális rendszer, ami később a kifejlett „jóléti állam” egyik mintapéldája lett. Beveridge tervezeteinek legrészletesebben kibontott része a társadalombiztosítást érintette, de más, kevésbé ismert javaslatai a foglalkoztatásra, a tervezésre és az államosításokra is kitértek.

A társadalombiztositásról és a hozzá kapcsolódó szolgáltatásokról szóló Beveridge jelentés (1942) fontos újdonsága a fábianizmusból eredeztethető átfogó jelleg: a társadalombiztosítás jövedelemtől (rászorultságtól) és foglalkoztatástól függetlenül mindenkinek kötelező. Fontos különbség azonban, hogy míg az előbbi elméletben a részesedés állampolgári jog, az utóbbi biztosítás alapú. ${ }^{9} \mathrm{~A}$ javaslat célja a jövedelembiztonság minimális szintjének megteremtése munkanélküliség, betegség, öregség és rendkívüli élethelyzetek esetére. Kockázatközösséget és szolidaritást jelent, de a szolgáltatások feltétele az egyének közremúködése és hozzájárulása: a finanszírozás forrása a munkavállalói és munkáltatói befizetés, amit az állami költségvetés csak kiegészített.

A biztosítási rendszert a javaslat szerint a hasonló elvekre épülő egészségügyi ellátásnak, a gyermeknevelés támogatásának, nem-kormányzati szolgáltatásoknak, valamint a foglalkoztatás növelését-fenntartását segítő állami intézkedéseknek kell kiegészítenie. Ez utóbbi, a teljes foglalkoztatásról szóló dokumentum az állami tulajdont érintő explicit javaslat miatt külön figyelmet érdemel. Beveridge kiindulópontja itt az, hogy a két háború közötti tartós és magas munkanélküliség társadalmi és morális probléma: „....a jövedelembiztonság nem alkalmas a tömeges munkanélküliség kezelésére, vagyis a társadalombiztositás önmagában nem teremt jó társadalmat" (Beveridge 1944: 4). Ehhez szükség van tervezésre, állami költekezésre és szabályozásra, valamint köztulajdonra is.

A teljes foglalkoztatás megteremtésére - amit Beveridge legfeljebb három százalékos munkanélküliségként definiál - az államnak is felelősséget kell vállalnia, de „szabad társadalomban”, azaz a szabadságjogok és a magántulajdon fenntartása mellett. A legfontosabb eszköz a foglalkoztatáshoz szükséges kiadási szint elérése; ha a magánköltekezés nem elegendő, akkor az éves költségvetésben ezt ki kell pótolni a kívánatos szintig inkább adóbevételekből, de akár deficit-finanszírozás árán is. Ezt pedig tervezéssel, egy Nemzeti Beruházási Bizottság felállításával, a magántőke terelésével és ösztönzésével lehet elérni, amihez a termelési eszközök, vállalatok állami tulajdona nem elengedhetetlen feltétel: a háborús tapasztalatok is azt mutatják, hogy az erős szabályozás nagy léptékű államosítások nélkül is megvalósítható, „inkább a keresletet, mint a termelést kell szocializálni" - írja Beveridge (1944: 27). De konkrét javaslatai (a társadalom- és egészségbiztosítás, a magánberuházások támogatása és szabályozása, a költségvetési kiadások megfelelő szintjének biztosítása és más intézkedések mellett) hangsúlyozzák az állami szektor kiterjesztését is, mert ez elősegíti a beruházások stabilizálását és a monopóliumok ellenőrzését (i.m.: 40).

9 Beveridge maga elutasította, a javaslat lényegének félreértéseként minősítette a „jóléti állam” elnevezést, helyette a „szociális szolgáltatások állama" kifejezést ajánlotta, hogy inkább a kötelezettség, mint a jogok kapjanak hangsúlyt. https://julesbirch. com/2012/11/27/10-things-you-may-not-know-about-the-beveridge-report/ 
A bemutatott korai jóléti elméletek tehát különféleképpen kezelték az állami tulajdonlást, mint a kívánatosnak tartott új társadalmi rend egyik lehetséges összetevőjét. A két szélsőség a teljes elutasítás-negligálás (a konzervatív irányzatokban), illetve a fontosnak minősités (fábiánusok, Beveridge). Köztes, mérlegelő álláspontot foglalt el Pigou, a svéd szociáldemokraták pedig elvileg nem zárták ugyan ki a termelési eszközök közkézbe vételét, de azt gyakorlatilag célszerútlennek ítélték; helyette az állami beavatkozás két másik módszerére, a szabályozásra és a szociálpolitikára összpontosítottak.

Nézzük ezután a második generációsnak nevezett elméleteket, amelyek az 1950-es évektől kezdve nem önmagában a jólét növelésének lehetőségeit, hanem - most már alapvetően pozitív-értelmező megközelítéssel - a múködő „jóléti államokat” vizsgálták. De mi is ez az új berendezkedés? Meghatározását az úttörők közé tartozó Asa Briggs (1961: 9) is hiányolta, és a téma jeles kutatója, Esping-Andersen (1990) szerint ezt az ürt a következő harminc évben sem sikerült betölteni. Ő maga kiindulópontként két felfogást különböztet meg. A fogalom szűkebb értelemben a szociális helyzet javításának hagyományos területeit jelenti (jövedelem átcsoportosítást, szociális szolgáltatásokat, esetleg a lakáshoz jutás segítését), tágabb értelemben pedig „...az állam nagyobb szerepvállalását a gazdaság menedzselésében és szervezésében," beleértve a foglalkoztatást és az egész makrogazdasági irányítást „...ez a megközelités 'a Keynesi jóléti államként' vagy ha tetszik, 'jóléti kapitalizmusként" határozza meg a tárgyát" (Esping-Andersen 1990: 1-2).

A keynesi tanokhoz füződő viszony elemzését szem előtt tartva számunkra ez utóbbiak érdekesek, azok, amelyek nem a szociális ellátások mennyiségi mutatót, hanem annak intézményi kereteit, múködési mechanizmusait és hatásait vizsgálják. Közülük Esping-Andersen mindmáig leginkább elfogadott elméletét idézzük fel részletesebben, amely erősen történeti szemléletű: bár a tipizálás alapadatai az 1980-as évekből származnak, a szerző hangsúlyozza a társadalomszerkezeti és intézményi adottságok, az útfüggőség meghatározó szerepét. Ez teremt lehetőséget arra, hogy a viszonylag kései teóriát összevessük a keynesi elgondolásokkal, illetve a második világháború utáni államosítások elméleti hátteréhez kapcsoljuk.

Új politikai gazdaságtanra van szükség a jóléti állam értelmezéséhez, de a klasszikus kérdésből, az állam és a piac viszonyából kiindulva - írja a dán szociológus. A jóléti kapitalizmus a munkaerő áru jellegének korlátozására épül, amelynek a társadalmi rétegződést, az egyenlőtlenségeket is meghatározó típusait a nagy társadalmi csoportok közötti politikai koalíciók sajátosságai alakítják ki.

„Az áru-jelleg megszünéséröl (de-commodification) akkor beszélhetünk, amikor egy szolgáltatást jogosultság alapján nyújtanak, és amikor egy személy anélkül képes biztositani létfenntartást, hogy a piacra támaszkodna" - állítja Esping-Andersen (1990: 22-23). A kiindulópontot Polányi Károlynak (2004 [1946]) a szélsőségesen kiterjesztett áruviszonyok romboló hatására - a piaci önszabályozás és a társadalom védekező mechanizmusai közötti folyamatos feszültségre -, valamint T. H. Marshallnak (1950) a polgári és politikai jogokat kiegészítő szociális jogokra vonatkozó elmélete adja. ${ }^{10} \mathrm{~A}$ szerző szerint a piaci erőktől való függetlenedés mérhető - ennek különböző fokozatai és következményei a jóléti államok típusképző ismérvei. A dekommodifikáció a liberális (angolszász) rezsimekben a leggyengébb, amelyek szelektíven, rászorultság alapján viszonylag kevés 
forrást osztanak el, közvetve és közvetlenül is a piac szerepét erősítik, és duális társadalmi szerkezetet eredményeznek. A közepes mértékkel jellemezhető konzervatív (kontinentális) típus a foglalkoztatottakra összpontosít, a juttatásokat társadalmi státus szerint differenciálja, így erősíti ezt a megosztottságot, mérsékelten enyhíti a szegénységet. A szociáldemokrata (skandináv) jóléti rendszer állampolgári jogon és nagyvonalúan nyújtja a szolgáltatásokat, az érintett területeken a piac helyébe lép, így az egyenlőtlenségek itt a legkisebbek. ${ }^{11} \mathrm{~A}$ mintapélda sorrendben az Egyesült Államok, Németország és Svédország. A különbségek kialakulásának meghatározó eleme a társadalmi szereplők (osztályok) koalícióalkotásának módja, a hatalmi erőforrások mértéke és felhasználása, amelynek hátterében a munkásosztály szerveződésének, az osztály-preferenciáknak és a politikai magatartás intézményesülésének eltérései állnak. ${ }^{12}$

A tulajdonlás kérdése Esping-Andersennél néhány elszórt utalástól eltekintve ${ }^{13}$ a munkaerőpiaccal és a foglalkoztatással kapcsolatban merül fel, de csak a szociális területet érinti. A szolgáltatások bővülésével az állam nagy munkaadóvá válik, befolyásolja a munkaerő keresletét, és ebben a szegmensben korlátozza a piaci mechanizmusokat. „Nem foglalkozunk az általában vett közszektorral. Ha a jóléti állam és a munkaerőpiac interakciójára vagyunk kiváncsiak, a közkézben lévő ipari, közlekedési vagy hírközlési vállalatok irrelevánsak, csakúgy, mint a közigazgatás az igazságszolgáltatás és rendfenntartás hagyományos területei. Az érdekel bennünket, hogy milyen mértékben dominálják a kollektiv jóléti szempontok a piacot a munkaerő allokációjában" - írja Esping-Andersen (1990: 157). További magyarázat hiányában nem világos ugyan, miért ne tartozna ebbe a körbe az „általában vett közszektor” egésze, hiszen ott ugyanúgy a piac háttérbe szorításáról van szó, akár a munkalehetőségek szempontjából is. A könyv azonban ezután csak az egészségügyi, oktatási és jóléti szolgáltatások állami-munkáltatói szerepét elemzi. A foglalkoztatás növelése kapcsán szó esik valamiféle átváltásról „a kormányzati hitelek, beruházások, államositások és a támogatások, adózás, foglalkoztatás és a jóléti politikák" között (i.m.: 187), de ez az utalás is kifejtés nélkül marad.

Úgy tűnik, hogy az ilyenfajta megközelítés széles körben elterjedt: az 1945 utáni jóléti teóriákban a köztulajdon jelen van - de csak a szociális szektorban válik láthatóvá. Jellegzetes példa erre a jóléti államok politikai gazdaságtanával foglalkozó, Csaba Iván és Tóth István György szerkesztette kötet (1999) alapos áttekintést adó bevezetője.

A szerzők szerint a jóléti államok tipizálásának egyik lehetséges szempontja az allokációs és disztributív döntések intézményi megoldásainak mintázata. Ebben a keretben az állami beavatkozásnak három csoportja van: a szabályozás, a jövedelem-újraelosztó programok és a közületi szektor egy részének múködtetése. A forma pedig lehet a fogyasztói döntések korlátozása, pénzbeli transzfer, ártámogatás és természetbeni juttatás - az utóbbi esetben az állam nemcsak finanszíroz, hanem szolgáltat is. „A jóléti szektorban az állami és nem állami intézmények részben helyettesithetik egymást (vagyis az állami beavatkozásnak lehet 'kiszorítási

11 Maga a tipizálás Lebeaux és Wilensky, valamint Titmuss modelljeire is támaszkodik, akik reziduális és univerzális jóléti államokat, illetve „ipari teljesítmény alapú” és „intézményesített” rendszereket különítettek el. A jóléti elméletekről összefoglalóként lásd Csaba-Tóth (1999).

12 Lásd erről és más magyarázó elméletekről Gedeon (2011).

13 Az államosítások elutasítása az 1920-as, 1930-as évek svéd és norvég példája kapcsán kerül szóba, az USA-t pedig a könyv a nyugdíjjogosultság kiterjedésével összefüggésben említi, amit az akkori államosítások, az állami alkalmazottak számának növekedése okozott (Esping-Andersen 1990: 12, 94-95). 
hatása'), részben egymással komplementer viszonyban állnak." A különböző tulajdonosi hátterű intézmények kombinálásával kialakul „a jólét vegyes gazdasága,” például a több pillérre épülő nyugdíjrendszerekben (Csaba-Tóth 1999: 20). De vegyes gazdaságról ennél szélesebb, a tulajdonviszonyok egészére kiterjedő értelemben itt is alig esik szó. ${ }^{14}$

A jóléti állam működését értelmező, második generációs publikáció-tömeg feldolgozására nem tudok vállalkozni, de néhány alapmű és összehasonlító elemzés alapján megkockáztatom azt a feltételezést, hogy ezek az elméletek még kevésbé foglalkoznak az állami tulajdon kérdésével, mint korai társaik. A téma legfeljebb a szükebb szociálpolitikai területen belül bukkan fel, abban a formában, hogy valamilyen állami szervezet közvetlenül nyújtja-e ezeket a szolgáltatásokat - ami szintén fontos kérdés, de a gazdaság egészében terjedő köztulajdonnak nem ad teoretikus hátteret.

Nézzük meg ezután, hogyan kezelte a tulajdon ügyét a „keynesi jóléti rendszer” másik elméleti komponense!

\section{A KEYNESI ELMÉLET ÉS A „KEYNESIANIZMUS”}

Az 1920-as években nemcsak a hagyományos („ó-liberális”) gazdaságfelfogás bírálata, hanem a keynesi Általános elmélet gazdaságpolitikai elemei is benne voltak a levegőben. Maga a szerző és mások is tettek hasonló javaslatokat, sőt ezek - mint az említett svéd példa mutatja - a gyakorlatban is érvényesültek. John Kenneth Galbraith (1988) szerint a keynesi tan az új gazdaságpolitikák programoknak nem kiindulópontja volt, hanem „kikristályosodási pontja”.

Keynes már 1924-ben megjelent hetilap-cikkében azt javasolta a kormánynak, hogy a munkanélküliség csökkentésére állami beruházásokkal adjon élénkítő lökést a gazdaságnak. Öt év múlva a liberális párt választási programjának részeként is ezt ajánlotta, utalva a multiplikátor hatásra is - úgy, hogy elemélet helyett a „józan észre," ráadásul a közgazdászok általános egyetértésére hivatkozott. Nem alaptalanul. Lee (1989) hosszan sorolja az előfutárokat, köztük az azóta elfeledett, de a korszakban széles körben ismert amerikai „amatőr közgazdászokat", akik hasonló nézeteket népszerűsítettek, nagy sikerrel.

Az akadémiai tudomány köréből is hozva egy példát, a Keynes-tanítvány Richard Kahn is az államilag finanszírozott közmunkák fontosságát hangsúlyozta a foglalkoztatás bővítése érdekében, már az 1930-as évek elején: „Az elsődleges foglalkoztatás növelése nyomán emelkedő bérek és profitok által teremtett kereslet kielégitésére megnő a fogyasztási cikkek termelése. Így ezekben a szektorokban is nőnek a bérek és profitok, és ezek a hatások tovagyürüznek, bár csökkenő intenzitással. És így tovább, a végtelenségig” (Kahn 1931: 173), majd modellezte is a multiplikátor hatás nagyságát.

14 A tanulmány említi ugyan a magántulajdon és a privatizáció melletti érveléseket, de csak az állami terjeszkedés kordában tartása kapcsán, nem hozva ezeket közvetlen összefüggésbe a jóléti államokkal.

Érdemes megjegyezni, hogy hasonló hiátus jellemzi a redisztribúciós mechanizmusok kutatását is. Sem a szociológiai, sem a közgazdasági szakirodalomban nem szokás egységes szemléletben vizsgálni a jóléti és a gazdaságon belüli újraelosztást (például az állami támogatásokat, vállalat- és bankmentéseket, a közforrásokból finanszírozott fejlesztéseket). Ritka és ígéretes kivételnek számít Czibere-Gerő-Kovách (2017) friss tanulmánya. 
Ezt a mechanizmust, valamint a közösségi beruházások növelését, mint tudjuk, John Maynard Keynes is alapvetőnek tekintette. Ha elméletét elemekre bontjuk, mint ezt Peter Hall (1989c) teszi, akkor három szint különböztethető meg: a közgazdasági teória megreformálása, egy sajátos javaslat az anticiklikus kínálat-vezérlésre, valamint az állami aktivitás kiterjesztése. Mivel a gondolatrendszer összetett - és a kritikusok szerint számos ponton a kifejtés sem egyértelmú - itt is tág tere van a különféle elméleti és gazdaságpolitikai értelmezéseknek. Winch meggyőzően érvel amellett, hogy a szerző maga az első két szintet tartotta fontosnak - nevezzük ezt a keynesianizmus szűkebb fogalmának -, a harmadikat a gazdaság egészének menedzseléseként értelmezte. „....a makrogazdasági szabályozás keynesi technikáit világosan meg kell különböztetni a gazdasági tervezés más formáitól, nem utolsó sorban azért, mert maga a fö épitömester az állami beavatkozás más, dirigistább formáival szembeni alternativaként határozta meg saját rendszerét” - ő maga ebből a szempontból „minimalista” volt (Winch 1989: 109, 124, kiemelés az eredetiben).

Az Általános elmélet elismeri ugyan, hogy a teljes foglalkoztatás érdekében tett lépések a hagyományos állami funkciók kiterjesztését jelentik, ami azonban szerzőjének felfogása szerint nem vezet a gazdasági élet zömét átfogó államszocializmushoz. „Ezért úgy vélem, hogy a beruházások meglehetősen átfogó szocializálása bizonyul majd az egyetlen eszköznek a teljes foglalkoztatás megközelítéséhez" - írja. Ugyanakkor széles tevékenységi területek érintetlenek maradnak. „Az állam számára nem a termelési eszközök tulajdonlása a legfontosabb. Ha az állam képes arra, hogy meghatározza az eszközök növelésére szolgáló források nagyságát és a tulajdonosoknak járó jövedelem alaprátáját, akkor minden feladatát teljesitette. A szocializálás szükséges intézkedései pedig fokozatosan, a társadalom általános hagyományainak megtörése nélkül megtehetők" (Keynes 1936: 238), de Keynes sem itt, sem a beruházásokkal kapcsolatban nem fejti ki világosan a szocializálás mibenlétét.

Mindenesetre saját rendszerét „mérsékelten konzervativ”-nak nevezte, és szenvedélyesen - noha nem megszorítások nélkül - érvelt az individualizmus, a szabadság megőrzése mellett. „...az individualizmus, ha meg lehet tisztitani a fogyatékosságaitól és a túlkapásoktól, a személyes szabadság legjobb őre, amely minden más rendszernél jobban kiterjeszti az egyén választási lehetőségeket és az élet sokszínúségét." Az állami szerep növelésére most éppen azért van szükség, mert ez „...az egyetlen gyakorlati eszköz arra, hogy elkerüljük a ma létező gazdasági formák teljes lerombolását, és ez a feltétele az egyéni kezdeményezések sikeres múködésének" (i. m.:239). Vagyis ez a kapitalizmus és a demokrácia megmentésének egyetlen útja - állítja Keynes -, minden más autoriter rendszerekhez vezet, mert az emberek nem tűrik tovább a munkanélküliséget, amit a szabadversenyes kapitalizmus önérdekkövetésének tulajdonítanak.

Hozzá kell tenni, hogy az elmélet mindenképpen radikális abból a szempontból, hogy a kapitalizmusnak ennél is lényegesebb megváltozását - talán azt is mondhatnánk, eddig feltételezett lényegének elvesztését vetíti előre. A tőke mennyiségét ugyanis nem nehéz olyan szintre emelni, írja az Általános elmélet, ahol a határhatékonyság nagyon alacsonnyá válik, vagyis a tőke szúkösségének megszűnésével a funkcióját vesztett beruházó már nem kap juttatást. „...ez a járadékosok eutanáziáját jelentené, következésképpen a kapitalisták elnyomó hatalmának az eutanáziáját, amely a töke szükösségén alapul ... Ezért úgy látom, hogy a kapitalizmus járadékos formája átmeneti fázis, amely eltünik, amikor megtette a magáét" (i.m.: 237) - mégpedig fokozato- 
san, békés úton, azoknak a folyamatoknak a továbbgördülésével, amelyek akkoriban már láthatók voltak NagyBritanniában.

Dokumentálható, hogy Keynes nem rokonszenvezett a gazdaság aprólékos vezénylésével, az „üzletellenes" fellépésekkel és a köztulajdon kiterjesztésével. Alapmúvében ezt az előbb idézett félmondaton túl nem is említi, a korabeli angol államosításokért pedig nem lelkesedett (Winch 1989). A későbbi jóléti állam másik két fontos alkotórésze sem szerepelt az elméletben. A nagyhírű közgazdász nem foglalkozott az akkoriban sokhelyütt, köztük Angliában is egyre népszerúbbé váló tervezéssel, amit fenntartásokkal kezelt, sőt a teória némelyek szerint inkább ennek „mértéktartó alternativáját” jelentette (Weir 1989: 74). Elméletének nem része továbbá a szociális újraelosztás sem - ez a kérdés nem érdekelte különösebben („Keynes soha nem volt szenvedélyes szociális reformer" - idézi életrajzíróját, Skidelskyt Marcuzzo 2005: 5). Bár támogatta William Beveridge javaslatát az átfogó társadalombiztosítási rendszer kialakítására, ugyanakkor a modern szociálpolitika atyja a kezdeti elutasítás után, eredeti neoklasszikus közgazdasági nézeteitől eltávolodva egyre inkább hajlott a keynesi elmélet elfogadására (Marcuzzo 2005), az erre építő korabeli gazdaságpolitikai kormányprogramot pedig „korszakalkotónak" nevezte (Beveridge 1944: 28), világos, hogy ezeken a pontokon elgondolásaik különböztek egymástól.

Keynes a megoldáshoz a termelés oldaláról közelítve nem lelkesedett a magas adókért, és eleinte aggódott a széles körú társadalombiztosítás hosszabb távú költségvetési hatásai miatt - később már úgy vélte, hogy az összjövedelem emelkedése megteremti majd a pénzügyi hátteret (Marcuzzo 2005). Beveridge pedig, mint szó volt róla, pártolta a tervezést és az állami tulajdont is, miközben a keynesi javaslatok több elemét, köztük a közmunka középpontba állítását is bírálta. Véleménye szerint az egyrészt nem praktikus, mert nem a reális szükségletekre épít, és nem számol a munkaerő-mobilitás korlátaival, másrészt nem elég radikális, mert a munkaerő-keresletnek csak a ciklikus, nem pedig a tervezést mellőző gazdaságokban krónikussá vált hiányát kezeli, továbbá a beruházások zömét magánkézben hagyja, és nem szakít a költségvetési ortodoxiával (Beveridge 1944: 32-35).

Rövid kitérőként hadd idézzek fel egy korabeli hazai példát a tervezés pártolásáról. Ez azt az állitást is illusztrálja - amelyet Ormos Mária (2004) könyve részletesen kifejt -, hogy a második világháború előtt magyar közgazdászok legjobbjai naprakészen ismerték a külföldi elméleteket, és figyelemmel kísérték a nyugati gyakorlat alakulását.

A liberális gazdaságpolitikához többé-kevésbé határozottan ragaszkodók (mint Navratil Ákos, Heller Farkas, Surányi-Unger Tivadar) mellett voltak olyan szerzők, akik „...a politikai és személyi szabadságjogok fenntartása mellett jóval radikálisabban képviselték az 'irányítás' és részleges tervszerüség programját" (Ormos 2004: 192) - de a szó szúkebb értelmében véve nem voltak keynesiánusok. Közéjük tartozott Malcomes Béla, aki szerint a liberális rendszer korábbi formájában megbukott, mégpedig jórészt azért, mert „már magát a liberalizmus fogalmát is túlságosan liberálisan értelmezte... A szabad kereskedelmi elv alkalmazása nem volt egyéb, mint az erősebbnek a nemzetközi gazdasági forgalomban biztosított ököljog... A liberálizmus jegyében nagyra növekedett magángazdaság sok tekintetben az államhatalom fölé kerekedett, és a közérdeket háttérbe szorította. A világgazdaság keletkezőben lévő új politikája a szociális és az állami eszme fokozottabb befolyása alá került. A szabadkereskedelmi irányzat letört”. Az egyes országokban már bevezetett rend lényege a „józan 
tervszerüség”. Ez nem a „tőkegazdasági rendszer” ellen irányul, hanem az individualizmus erősebb korlátozásával, a közérdek érvényesítésével „a kapitalizmus végre szociálisan is fokozottabban megindokolható hivatását” alapozhatja meg (Malcomes 1936: 43-47). Ebben megítélése szerint több európai ország mellett az Egyesült Államok is élen járt.

Az utóbbi hivatkozás nem megalapozatlan. Voltak akkoriban olyan amerikai javaslatok, amelyek az eddig idézett elgondolások mindegyikénél keményebben fogalmaztak. Rexton Tugwell (1932) például átfogó, az öszszes ágazatra kiterjedő tervezést ajánlott, amely meghatározná a tôkefelhalmozás irányát, korlátozná a cégek piacra lépését és terjeszkedését, hozzáigazítaná a termelést a kereslethez - általános ár- és profitellenőrzést jelentene. Ilyen feltételek mellett az új a rendszerben „....a vállalkozásnak (business) el kell tünnie. Ez nem a hangsúly nyomatékositására szolgáló túlzás, hanem szó szerint kell érteni" (Tugwell 1932: 89). A változásokat nem egyszerre vezetjük be - írja -, fokozatos módosítások lesznek. De a laissez faire intézményeit le kell rombolni, amihez az alkotmányos rend átalakitása is szükséges. Vagyis e felfogás szerint a magángazdálkodás a szigorú szabályozás, nem pedig köztulajdonba vétel útján „tűnik el”.

Bár Tugwell Roosevelt elnök agytrösztjének tagja volt, a változás persze nem lett ennyire szélsőséges. Sok ponton módosította azonban a gazdaság és a társadalom múködési kereteit. Az Általános Elmélet megjelenése előtt elindított, szociálliberálisnak nevezett New Deal tartalmazott foglalkoztatás- és keresletnövelő elemeket - ez a gazdaságélénkítés Salant (1989) elemzése szerint csak 1938-tól vált alapvetővé -, de az egyéb programok listája is hosszú. Többek között új hatóságok jöttek létre, megváltoztatták a bankok, az értékpapír forgalom, valamint a munkaviszonyok szabályozását, új állami vállalkozások alakultak, és az 1935-ben elfogadott társadalombiztosítási törvény a központi állam pénzügyi hozzájárulásával bevezette a nyugdíjrendszert, a munkanélküli segélyt és a gyermeknevelés támogatását. Az USA-ban, Angliától eltérően, a keynesi program az 1930-as években összekapcsolódott a tervezéssel és a jóléti rendszer kiterjesztésével ${ }^{15}$ mind intellektuálisan, mind pedig a politikai porondon (Weir 1989).

Az Egyesült Államok esete a korábban felvillantott angol és svéd példákkal együtt azt mutatja, hogy nemcsak a jóléti rendszerek alakításában, hanem a szúkebben definiált keynesianizmus politikai értelmezésében, elfogadásában, alkalmazásának idejében és módjában nagyok voltak az országok közötti különbségek. Ezt alaposan és tanulságosan elemzi a Peter Hall (1989a) által szerkesztett kötet, amely az eltéréseket komplex indokokkal - a gazdaságok, az állami intézményrendszer és a tudományos élet szerkezetével, a pártok ideológiájával és hatalmi viszonyaival, az állam és a társadalom történetileg kialakult kapcsolatával, a politikai diskurzus szerkezetével - magyarázza. E csoportosítás szerint az elmélet hatása először az USA-ban és Svédországban volt a legnagyobb, majd a világháború után Angliában is; a németek, a franciák, az olaszok, a dánok és a finnek viszont - különböző okokból - később is csak visszafogottan alkalmazták.

Ez a felosztás nem vág egybe Esping-Andersennek a jóléti államokra adott hármas tipológiájával - részben az elemzés fő szempontjának különbsége miatt -, de fóképpen valószínúleg azért, mert a keynesi és a jóléti rendszereknek nemcsak a megvalósítása tér el országonként, hanem maguk az elméletek is különböznek.

15 Igaz, hogy ezek a maguk idejében úttörő lépések 1945 után megtorpantak, és sokáig folytatás nélkül maradtak (Esping-Andersen 1990) 


\section{Államosítások - elmélet nélkül}

Elemzésünk középponti kérdése, az állami tulajdon kiterjesztése szempontjából az a legfontosabb következtetés, hogy ehhez a keynesianizmus - legalábbis az elméletet és a gazdaságpolitikai javaslatot nézve - nem adott eszmei keretet. A jóléti teóriák zömében sem szerepel a köztulajdon. A kivételek - az itt bemutatottak közül a fábiánus mozgalom, Pigou és Beveridge - a korai elgondolások közé tartoznak, az 1945 utáni írások ezt általában csak egy szúkebb területen, a szociális szolgáltatások intézményeivel kapcsolatban említik. Mivel a második világháború után a fejlett országok a Keynesre hivatkozó jóléti állam valamilyen formáját vezették be, és ugyanakkor nagy - bár nem egyforma mértékű - államositási hullám is kezdődött, ez utóbbinak valójában nem volt elméleti megalapozása. A jelenség okainak mérlegeléséhez hozzásegít a keynesi és a jóléti teóriák viszonyának összegzése.

Ha mindkét felfogás szűkebb értelmezését vesszük alapul (azaz a jóléti államot Esping-Andersen meghatározása nyomán a szociálpolitikával, a keynesianizmust pedig az eredeti forrásból kiindulva egy új teória, illetve az anticiklikus gazdaságpolitika új módszerével definiáljuk), akkor a két irányzat korántsem azonos, annak ellenére, hogy az általánosságok szintjén sok a hasonló vonás. A jóléti elméletek és a keynesianizmus és egymáshoz közel álló problémára kerestek választ. Ez először a szegénység, azaz a jövedelemhiány, ami összefügg a munkalehetőséggel is, majd az 1920-as évektől a tömeges munkanélküliség - innentől kezdve a foglalkoztatás kitüntetett szerepe szoros kapcsolatot teremt a két irányzat között. Közös a kiindulópont is, a kétkedés abban, hogy a piaci önszabályozás a legjobb megoldás a társadalmi-gazdasági bajok orvoslására. A kapitalizmust a bemutatott elméletek többsége hosszú távra nem tartja a legjobb berendezkedésnek - mint láttuk, ez nemcsak a szocialistákra, szociáldemokratákra, hanem Keynesre is áll -, de a változásokat békés, fokozatos úton, a szabadság és a demokrácia fenntartásával gondolják el. Közös továbbá a javaslat fő iránya is: a piacgazdaság keretein belül az állami felelősség és szerepvállalás növelése, azaz a magántulajdonhoz füződő jogok korlátozása, a közösségi értékek érvényesítése az individualisztikus szempontok rovására.

A konkrétumokat nézve azonban szembeötlőek a különbségek. Keynes alapvetően gazdasági nézőpontból, kifejezetten a recessziós időszakok makrogazdasági politikájához adott programot, a ciklikus munkanélküliség enyhítése érdekében. A kereslet élénkítése az állami kiadások emelkedésével jár ugyan, és növelheti a költségvetési hiányt, de jó esetben csak átmenetileg. ${ }^{16} \mathrm{~A}$ jóléti állam magját adó szociálpolitika ellenben a társadalmi egyenlőtlenségek mérséklésére, a nehéz élethelyzetek kezelésére irányul, amelyeknek a munkanélküliség csak az egyik megjelenése. A válságperiódusokon túlmutató, strukturális problémák megoldása többékevésbé széleskörű és tartós jövedelem újraelosztást igényel, hosszabb távon is felduzzaszthatja a kormányzati redisztribúciót. A keynesianizmusban a magántulajdon (az „individualizmus”) korlátozása a beruházási döntésekre, azaz döntően a termelésre összpontosul, míg a jóléti elvek a piac (az áru jelleg) szélesebb körű háttérbe szorítására építve elosztás-centrikusak.

Ebből következően a keynesi rendszer nem okvetlenül jóléti jellegű a szó szúkebb értelmében - a szociálpolitika nem szerves része -, és megfordítva, a jóléti berendezkedés nem feltételezi a beruházásokat növelő 
fiskális politikát. Ugyanakkor a kétféle megközelítés nem zárja ki egymást, ellenkezőleg, kölcsönösen erősithetik a másik hatását. Az összkereslet fenntartásához hozzájárulhatnak a szociális újraelosztásból - társadalombiztosításból, családtámogatásokból, a rendszert múködtető adminisztráció finanszírozásából - adódó automatikus stabilizátorok, a gazdaságélénkítés sikere viszont egyrészt csökkenti az elosztó rendszerekre nehezedő nyomást, másrészt megnagyobbítja azt a tortát, amit szeletelni lehet.

Ahol a két megközelítés a hasonló kiindulópontokon és ezen a komplementer jellegen túl összetalálkozik, az a felfogások tág értelmezése. Így nézve a közös lényeg az állami szerep kiterjesztése - ami viszont annyira sokrétű, hogy szinte parttalan fogalomkör. Ennek ellenére, vagy éppen ezért lett ez a közkeletű felfogás, különösen a (gazdaság)politikában. A keynesi eszmerendszer gazdasági ciklusokat kisimító javaslatai vegyes fogadtatásra találtak ${ }^{17}$ miközben az állami aktivitás növelése egyértelműen népszerúvé vált. Az elmélet hivatkozási alapot adott a kormányzati szerep bővítéséhez, segített felpuhítani a nemzetállamok költségvetési korlátját, lehetőséget adva többek között nagy léptékű szociális programok elindítására és fenntartására is. Amikor 1945 után a konkrét körülmények - a hadigazdálkodás tapasztalatai, az újjáépítés és a biztonság igénye - elodázhatatlanná tették a változásokat, a keyenesizmus „olyan köpönyeggé vált, amely alkalmas volt elfedni vagy felöltöztetni a gazdasági gyakorlat sokféle változatát" (Hall 1989b: 5); magába foglalta a fiskális politikán túl a monetáris politikát, a tervezést, a szabályozást, a mikrogazdasági vezérlést és a széleskörű szociálpolitikát is. Ez lett a „keynesi jóléti állam”, a „Keynes plusz Beveridge” formula (Esping-Andersen 1990: 147), amely útfüggő módon, országonként változatos mintázatokban vegyítette az egyes eszközöket, így különböző kapitalizmustípusokat teremtett. ${ }^{18}$

A szociális szolgáltatások területén túllépő állami tulajdonlás perifériára szorulását az elméletekben az magyarázhatja, hogy a köztulajdon sem a keresletélénkítő politikának, sem a szociális újraelosztásnak nem elengedhetetlen feltétele. A magántulajdonosi rendszer államositás nélkül is korlátozható, megfelelő szabályozással múködtethető államvezérelten - mint ezt a hadigazdálkodás vagy a korai svéd példa is mutatta -, és a szolidaritás, az egyenlőség értékeit is lehet enélkül érvényesíteni. Ugyanakkor a kormányzati beavatkozás eszközeinek kombinálhatósága érvényes a köztulajdonra is: ez is beillesztethető a bővülő állami szerepkészletbe, a szabályozás-újraelosztás színes palettájába. Az állami szektor kiterjedésével szilárdabb bázist kap a makrogazdasági tervezés, közvetlen központi döntésekkel növelhetők mind a beruházások, a foglalkoztatás és a keresletet bővítő bérek, mind pedig - a vállalatok által nyújtott juttatások révén - a szociális jólét. De a komplementaritás mellett megjelenik a helyettesités lehetősége: a tulajdonlás kiválthatja a szabályozást és (főként a munkahelyteremtés révén) a szociálpolitika egy részét is. Noha ezeknek az átváltásoknak a felvetése a teóriákból kimaradt, a gyakorlati-politikai döntésekben fontos szerepet játszhattak, hozzájárulhattak a közszektor bővítéséhez.

17 Lee (1989) kimutatja, hogy 1945 előtt sok kormány ódzkodott a deficit-finanszírozástól a korábbi inflációs trauma és az azzal járó társadalmi zúrzavar miatt, továbbá attól tartva, hogy ez csökkentené autonómiájukat az üzleti körök és a szélesebb társadalmi csoportok erősödő nyomása következtében.

18 Ennek az utóbbi évtizedekben egyre bővülő irodalmát Peter Hall és David Soskice (2001) úttörő munkája nyomán a kapitalizmus változatainak (Varieties of Capitalism) címszava alatt találhatjuk meg. Az eredeti, Európára és az angolszász országokra összpontosító modell egyébként liberális és koordinált piacgazdaságot különböztet meg, amelyeknek mintapéldája az USA és Németország. Itt a csoportképző kritériumok a vállalatok kapcsolatrendszerén, a koordinációs mechanizmuson alapulnak, sem az állami tulajdon, sem a jólét nem szerepel közöttük. A későbbi tipizálások viszont sokszor tartalmazzák a szociális védelem, a jóléti rendszerek elemeit. 
Végül is az 1945 utáni államosítások szilárd elméleti alapok nélkül indultak el. Csak az állami szerep növekedésének általános, a keynesi jóléti államban összegződő keretfeltételei adtak nekik hátszelet - de természetesen ez sem kevés. 


\section{HIVATKOZÁSOK}

Berman, S. (2006) The Primacy of Politics: Social Democracy and the Making of Europe's Twentees Century. Cambridge: Cambridge University Press. https://doi.org/10.1017/cbo9780511791109

Beveridge, W. (1942) Social Insurance and Allied Sevices. London: His Majesy's Stationary Office. Elérhető: http://news.bbc.co.uk/2/shared/bsp/hi/pdfs/19_07_05_beveridge.pdf [Letöltve: 2017-10-11]

Beveridge W. (1944) Full employment in a Free Society. London: The New Statesman and Nations and Reynolds News. Elérhető: https://library.Ise.ac.uk/archives/beveridge/9A_79_Full_employment_in_a_free_society.pdf [Letöltve: 2017-10-11]

Briggs, A. (1961) The Welfare State in Historical Perspective, Archives Européennes de Sociologie, II. 221-258. https://doi.org/10.1017/s0003975600000412

Csaba I. - Tóth I. Gy. (szerk.) (1999) A jóléti állam politikai gazdaságtana. Budapest: Osiris - Láthatatlan Kollégium. Bevezetés, 7-37.

Czibere I. - Gerő M. - Kovách I. (2017) Újraelosztás és integráció. In Kovách I. (szerk.) Társadalmi integráció. Az egyenlőtlenségek, az együttmúködés, az újraelosztás és a hatalom szerkezetet a magyar társadalomban. Szeged - Budapest: MTA Társadalomtudományi Kutatóközpont Szociológiai Intézet - Belvedere Meridionale, 51-116.

Drechsler, W. (2016) Kathedersocialismus and the German Historical School. In Reinert, E. S. - Ghosh, J. - Kattel, R. (szerk.) Handbook of Alternative Theories of Economic Development. Edward Elgar Publishing, 109-123. http://dx.doi.org/10.4337/9781782544685.00011

Esping-Andersen, G. (1990) The Three Worlds of Welfare Capitalism. Princeton: Princeton University Press.

Galbraith, J. K. (1988) Egy kortárs emlékei. Budapest: Európa.

Gedeon P. (2011) Rivális elméletek a jóléti államról. Politikatudományi Szemle, 2, 7-30.

Hall, P. A. (szerk.) (1989a) The Political Power of Economic Ideas: Keynesianism across Nations. Princeton, New Jersey: Princeton University Press.

Hall, P. A. (1989b) Introduction. In Hall (1989a) 3-26.

Hall, P. A. (1989c) Conclusion: The Politics of Keynesian Ideas. In Hall (1989a) 361-392.

Hall, P. A. - Soskice, D. (szerk.) (2001) Introduction: Varieties of Capitalism. The Institutional Foundations of Comparative Advantage. Oxford: Oxford University Press.

Kahn, R. (1931) The Relation of Home Investment to Unemployment. The Economic Journal, (41)162, 173-198. https://doi.org/10.2307/2223697

Keynes, J. M. (1936) The General Theory of Employment, Interest, and Money. Elérhető:http://cas.umkc.edu/economics/people/ facultypages/kregel/courses/econ645/winter2011/generaltheory.pdf [Letöltve: 2016-05-30]

Lee, B. A. (1989) The Misscarriage of Necessity and Invention: the Porto-Keynesianism and Democratic States in the 1930s. In Hall (1989a), 129-170.

Loppert Cs. (2003) Sikerek és kudarcok az európai szociáldemokrácia történetében. Budapest: Századvég.

Madarász A. (2002) Kameralizmus, történelmi iskola, osztrák gazdaságtan. Három vázlat a német és osztrák közgazdasági diskurzus történetéből. Közgazdasági Szemle, 10, 838-857.

Malcomes B. (1936) A gazdaság új fejlődése. Az antiliberális irány rendszeres vizsgálata, különös tekintettel a nemzetközi vonásokra. Budapest: Dr. Vajna György és Társa.

Marcuzzo, M. C. (2005) Keynes and the Welfare State.

Elérhető: www.ie.ufrj.br/eventos/seminarios/pesquisa/texto_02_12.pdf [Letöltve: 2017-01-09]

Marshall, T. H. (1950) Citizenship and Social Class and Other Essays. Cambridge: Cambridge University Press.

Morel, N. - Palier, B. - Palme, J. (szerk.) (2012) Towards a Social Investment Welfare State? Ideas, Policies and Challenges. Bristol: Policy Press at the University of Bristol.

Ormos M. (2004) A gazdasági világválság magyar visszhangja. Budapest: PolgART.

Pease, E. R. (1916) The History of the Fabian Society. New York: E. P. Dutton \& Co.

Pigou, A. C. (1920) The Economics of Welfare. Elérhető: http://www.econlib.org/library/NPDBooks/Pigou/ [Letöltve: 2016-11-20]

Polányi K. (2004 [1946]) A nagy átalakulás. Korunk gazdasági és politikai gyökerei. Budapest: Napvilág.

Salant, W. S. (1989) The Spread of Keynesian Doctrines and Practices in the United States. In Hall (1989a) 27-52.

Skidelsky, R. (2009) The Return of the Master. New York: Public Affairs. 
Tawney, R. H. (1922) The Acquisitive Society. London: G. Bell and Sons Ltd. Elérhető: https://archive.org/details/acquisitivesocie00tawnuoft [Letöltve: 2016-07-18]

Tilton, T. A. (1979) A Swedish Road to Socialism: Ernst Wigforss and the Ideological Foundations of Swedish Social Democracy. The American Political Science Review, (73)2, 505-520. https://doi.org/10.2307/1954894

Tugwell, R. (1932) The Principle of Planning and the Institution of Laissez Fire. American Economic Review, March, 75-92.

Wallis, E. (szerk.) (2009) From the Workhouse to Welfare, What Beatrice Webb's 1909 Minority Report can teach us today. London: Fabian Society.

Webb, S. (1890) English Progress towards Social Democracy. London: Fabian Society. Elérhető: http://digital.library.Ise.ac.uk/objects/ Ise:viy575hih [Letöltve: 2016-01-11]

Webb, S. (1891a) The Municipalisation of the Gas Supply. Fabian Tract No. 32. Elérhető: http://digital.library.lse.ac.uk/objects/ Ise:yeq938bor [Letöltve: 2016-01-11]

Webb, S. (1891b) Municipal Tramways. Fabian Tract No. 33. Elérhető: http://digital.library.Ise.ac.uk/objects/Ise:yeq938bor [Letöltve: 2016-01-11]

Webb, S. (1891c) London's Water Tribute. Fabian Tract No. 34. Elérhető: http://digital.library.Ise.ac.uk/objects/Ise:put749cot [Letöltve: 2016-01-11]

Webb, S. - Webb, B. (szerk.) (1909) The Minority Report of the Poor Law Commission, Printed for the National Committee to Promote the Break-up of the Poor law. London. Elérhető: https://archive.org/details/b24872726_0001 [Letöltve: 2017-09-16]

Weir, M. (1989) Ideas and Politics: The Acceptance of Keynesianism in Britain and the United States. In Hall (1989a) 53-86.

Winch, D. (1989) Keynes, Keynesianism, and State Intervention. In Hall (1989a) 107-128. 